\title{
Fastidious spiral bacilli causing backbone infections after gastroenteritis
}

\author{
Koichiro Lee, Hideharu Hagiya, ${ }^{\circledR}$ Misaki Kageyama, Futoshi Nakagami
}

Department of General Internal Medicine, Osaka University Hospital, Suita, Osaka, Japan

Correspondence to Dr Hideharu Hagiya, e_dai_for_all@hotmail.com

Accepted 13 February 2019

\section{DESCRIPTION}

A 72-year-old man with a background of alcoholic hepatitis (Child-Pugh A) was transferred to our services after suffering from a prolonged fever, originally presenting a few days previously with vomiting and diarrhoea suggestive of gastroenteritis. Although his initial symptoms resolved spontaneously within several days, his fever continued with reportedly negative blood cultures. He was therefore referred to our hospital for further investigation and management.

Three weeks after the onset of gastroenteritis, the patient presented with a deteriorating lower back pain, resulting in difficulty in walking. Physical examination detected only a knocking pain at his lumbar region. Laboratory tests revealed a serum C-reactive protein level of $1.99 \mathrm{mg} / \mathrm{dL}$ and erythrocyte sedimentation rate of $102 \mathrm{~mm} / 2$ hours indicative of a slight inflammatory reaction. Further investigation with vertebral MRI revealed a bone fracture at the 12th thoracic vertebra accompanied by signal changes suggesting vertebral osteomyelitis at 12 th thoracic to 1 st lumbar and 4 th to 5 th lumbar regions (figure 1A, B). Accordingly, we diagnosed the case as vertebral osteomyelitis and initiated intravenous ampicillin ( $2 \mathrm{~g}$ four times daily).

Five days later, culture examination from aerobic blood drawn before hospitalisation revealed presence of Gram-negative spiral bacilli (BD BACTEC ${ }^{\mathrm{TM}}$ FX blood culture system; Becton Dickinson, Sparks, MD, USA) (figure 1C). The organism was identified as Helicobacter cinaedi by means of organism-specific PCR assay targeted to gyrase subunit B. Based on the diagnosis of $H$. cinaedi-induced vertebral osteomyelitis and

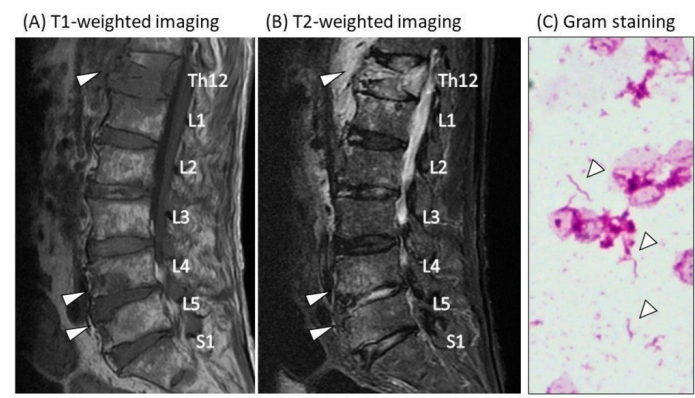

(C) BMJ Publishing Group Limited 2019. No commercial re-use. See rights and permissions. Published by BMJ.

To cite: Lee $\mathrm{K}$, Hagiya $\mathrm{H}$, Kageyama $\mathrm{M}$, et al. BMJ Case Rep 2019;12:e228290. doi:10.1136/bcr-2018228290 secondary bone fracture, we changed antibiotic treatment to cefotaxime ( $2 \mathrm{~g}$ three times daily). Contrast-enhanced CT scan did not reveal any aortic aneurysm or deep-seated abscess formation. Transthoracic echocardiography did not reveal any findings indicative of infective endocarditis. Bone mineral density of his femur neck was 59\% of the young adult mean value, suggesting the diagnosis of osteoporosis. The patient developed drug-induced neutropenia after receiving cefotaxime for 3 weeks; thus, ampicillin was chosen again for antibiotic therapy. After 6 weeks of intravenous treatment, the patient was discharged with oral doxycycline.

This is a case of bacteremia and vertebral osteomyelitis caused by $H$. cinaedi involving a patient with alcoholic liver cirrhosis. To our knowledge, this is the first case of bacteraemia and vertebral osteomyelitis caused by $H$. cinaedi involving multiple, non-contiguous vertebrae. This patient's clinical history suggests that his preceding gastroenteritis triggered a translocation of $H$. cinaedi across the gut, resulting in vertebral osteomyelitis with multiple, distinct points of infection. $H$. cinaedi is a Gram-negative spiral bacillus usually inhabiting the intestinal tracts of mammals. Using a pulse-field gel electrophoresis assay, recent literature demonstrates that $H$. cinaedi bacteraemia occurs as a result of bacterial translocation from gut. ${ }^{1}$

Considering the slow growth rate of $H$. cinaedi, one would expect the vertebral disease to progress relatively slowly and perhaps with a longer time between symptom onset and diagnosis compared with standard vertebral osteomyelitis cases (1.8 months on average). ${ }^{2}$ However, in this case, the presence of osteoporosis as a comorbidity, contributing to infection-induced vertebral fracture, resulted in a much earlier diagnosis. MRI can help distinguishing an acute-onset from that with chronic course. High and heterogeneous T2-weighted signal intensities are usually indicative of acute and chronic phases, respectively. ${ }^{3}$ In the presented case, the T2-weighted image homogeneously showed high intensity rather than heterogeneous intensity, suggesting a relatively acute phase of infection.

A recent report alluded that liver cirrhosis can be an underlying condition for $H$. cinaedi bacteraemia. ${ }^{4}$ The present case also indicated that decreased cellular and humoral immunity due to liver cirrhosis possibly poses a risk of infection by the relatively avirulent organism. Blood culture submitted for testing at another hospital failed to detect the organism. After enquiries, we noticed that the blood samples were incubated for only 4 days. $H$ cinaedi is a fastidious slow-growing 
pathogen, requiring four to 10 days of incubation period using automatic blood culture systems. ${ }^{5}$ This case highlighted the importance of extended blood culture incubation in diagnosing $H$. cinaedi infection.

\section{Learning points}

- Physicians should note that Helicobacter cinaedi can induce bacteraemia after gastroenteritis.

- Physicians should consider $H$. cinaedi when detecting Gram-negative spiral bacillus in blood culture, especially in immunocompromised patients.

- When $H$. cinaedi infection is suspected, duration of the blood culture examination should be extended up to about 7-10 days.

Contributors All the authors contributed management of the patient. HH mainly wrote the manuscript.
Funding The authors have not declared a specific grant for this research from any funding agency in the public, commercial or not-for-profit sectors.

Competing interests None declared.

Patient consent for publication Obtained.

Provenance and peer review Not commissioned; externally peer reviewed.

\section{REFERENCES}

1 Araoka H, Baba M, Okada C, et al. First evidence of bacterial translocation from the intestinal tract as a route of Helicobacter cinaedi bacteremia. Helicobacter 2018:23:e12458.

2 McHenry MC, Easley KA, Locker GA. Vertebral osteomyelitis: long-term outcome for 253 patients from 7 Cleveland-area hospitals. Clin Infect Dis 2002:34:1342-50.

3 Nickerson EK, Sinha R. Vertebral osteomyelitis in adults: an update. Br Med Bull 2016:117:121-38

4 Kamimura K, Kumaki D, Arita M, et al. First case of bacteremia caused by Helicobacter cinaedi in a patient with liver cirrhosis: a case report and literature review. Clin J Gastroenterol 2015;8:306-17.

5 Kawamura Y, Tomida J, Morita Y, et al. Clinical and bacteriological characteristics of Helicobacter cinaedi infection. J Infect Chemother 2014:20:517-26.

Copyright 2019 BMJ Publishing Group. All rights reserved. For permission to reuse any of this content visit https://www.bmj.com/company/products-services/rights-and-licensing/permissions/

BMJ Case Report Fellows may re-use this article for personal use and teaching without any further permission.

Become a Fellow of BMJ Case Reports today and you can:

- Submit as many cases as you like

- Enjoy fast sympathetic peer review and rapid publication of accepted articles

- Access all the published articles

Re-use any of the published material for personal use and teaching without further permission

For information on Institutional Fellowships contact consortiasales@bmjgroup.com

Visit casereports.bmj.com for more articles like this and to become a Fellow 